Penelitian

\title{
Potensi Infusa Kemiri (Aleurites moluccana) sebagai Analgesik dan Stimulator Stamina
}

\author{
(Potency of Candlenut Infusion (Aleurites moluccana) as an \\ Analgesic and Stamina Stimulator)
}

\author{
Fajar Anaba', Ni Luh Putu Ika Mayasari ${ }^{2}$, Andriyanto $^{3^{*}}$ \\ ${ }^{1}$ Mahasiswa Program Sarjana Fakultas Kedokteran Hewan, Institut Pertanian Bogor \\ ${ }^{2}$ Staf Pengajar Divisi Mikrobiologi Medik Departemen Ilmu Penyakit Hewan dan Kesehatan Masyarakat Veteriner, \\ Fakultas Kedokteran Hewan, Institut Pertanian Bogor \\ 3 Staf Pengajar Divisi Farmakologi dan Toksikologi Departemen Anatomi, Fisiologi, dan Farmakologi, Fakultas \\ Kedokteran Hewan, Institut Pertanian Bogor \\ *Penulis untuk korespondensi: andriyanto@apps.ipb.ac.id \\ Diterima 3 Juli 2020, Disetujui 15 Februari 2021
}

\begin{abstract}
ABSTRAK
Kesehatan merupakan hal penting untuk menjalankan aktivitas sehari-hari. Penurunan kesehatan dan daya tahan tubuh mengakibatkan timbul rasa nyeri serta mudah terserang penyakit. Pengobatan herbal digunakan sebagai pengobatan alternatif yang lebih aman dan terjangkau dibandingkan pengobatan nonherbal dari bahan-bahan kimia. Kemiri merupakan salah satu tanaman herbal yang memiliki banyak khasiat dan sering digunakan sebagai pengobatan oleh masyarakat. Penelitian ini bertujuan mempelajari efektivitas infusa kemiri sebagai analgesik dan stimulator stamina dalam berbagai dosis pada mencit. Uji efektivitas analgesik ditinjau menggunakan metode hot water immersion tail-flick test dan uji efektivitas stamina menggunakan metode natatory enhausen. Penelitian ini menggunakan 20 ekor mencit jantan yang dikelompokkan menjadi kelompok kontrol dan kelompok perlakuan yang diberi infusa kemiri dengan dosis 1, 2, dan $4 \mathrm{~g} / \mathrm{kg}$ BB. Setiap kelompok terdiri atas 5 ekor. Data dianalisis menggunakan analysis of variance (ANOVA) kemudian dilanjutkan dengan uji Tukey. Hasil penelitian didapatkan dosis efektif pada uji analgesik adalah $4 \mathrm{~g} / \mathrm{kg}$ BB dengan waktu respons nyeri ekor terlama yaitu 7.840 \pm 0.477 detik dan pada uji stamina adalah $1 \mathrm{~g} / \mathrm{kg}$ BB yang ditunjukkan dengan durasi berenang terlama yaitu 145.00 \pm 20.65 detik. Kemiri memiliki efektivitas terhadap analgesik dan stimulator stamina.
\end{abstract}

Kata kunci: analgesik, ANOVA, herbal, kemiri, stamina

\begin{abstract}
Being healthy is important to be able to carry out daily activities. Declined health and endurance will result in pain and susceptible to disease. Herbal remedies are used as a safer and more affordable alternative treatment to replace non-verbal treatments which contain chemicals. Candlenut is one of the herbs that has many benefits and is commonly used as a treatment by all. This study aims to investigate the effectiveness of candlenut infusion as an analgesic and stamina stimulator using various doses in mice. The analgesic effectiveness test was reviewed by the hot water immersion tail-flick test method while the effectiveness of stamina used the natatory exhaustion method (swimming endurance). This study comprised of 20 male mice which were grouped into 4, namely a control group and 3 treatment groups that were given candlenut infusion at a dose of 1, 2, and $4 \mathrm{~g} / \mathrm{kg}$ body weight. Each group consists of 5 animals. The data were analyzed by using analysis of variance (ANOVA) followed by Tukey test. The results showed that effective dose in the analgesic test was at a dose of $4 \mathrm{~g} / \mathrm{kg}$ BW of $7.84 \pm 0.48$ seconds while for the stamina test was at a dose of $1 \mathrm{~g} / \mathrm{kg}$ BW of $145.00 \pm 20.65$ seconds. It was concluded that the candlenut effective as natural analgesics and stamina stimulators.
\end{abstract}

Keywords: analgesics, ANOVA, herbal medicine, candlenut, stamina 


\section{PENDAHULUAN}

Sejak zaman dahulu, masyarakat di Indonesia sudah memanfaatkan tanaman sebagai obat herbal. Alam Indonesia dengan keanekaragaman hayati, diperkirakan memiliki potensi tanaman herbal sebanyak 30000 jenis, di antaranya sebanyak 940 jenis tanaman dinyatakan memiliki khasiat obat. Tanaman herbal digunakan untuk pengobatan berbagai penyakit dan peningkat stamina tubuh. Pengobatan menggunakan herbal kini lebih diminati oleh masyarakat dibandingkan dengan pengobatan nonherbal. Hal ini karena pengobatan menggunakan herbal memiliki efek relatif lebih kecil, sedangkan pengobatan nonherbal menggunakan bahan-bahan kimia yang memiliki efek samping lebih besar bagi kesehatan. Selain itu, peningkatan minat terhadap herbal di kalangan masyarakat dikarenakan herbal lebih terjangkau, baik harga dan ketersediaannya di alam (Nurrani, 2013).

Salah satu herbal yang umum digunakan oleh masyarakat Indonesia adalah kemiri dari famili Euphorbiaceae. Kemiri merupakan tanaman asli dari Indonesia dan tersebar di Asia Tenggara, Polinesia, Asia Selatan, dan Brazil. Bagian tanaman kemiri yang dapat digunakan sebagai obat herbal yaitu daun, kulit batang, hingga bijinya. Kemiri (Aleurites moluccana) mengandung flavonoid, polifenol, vitamin, folat, protein, karbohidrat, tanin, alkaloid, saponin, steroid, dan terpenoid. Masyarakat memanfaatkan kemiri untuk menumbuhkan rambut, menyembuhkan luka kulit, ulser, diare, asma, dan meningkatkan efek analgesik. (Adawiyah, 2017; Bilang et al., 2018).

Kesehatan tubuh merupakan hal yang sangat penting untuk melakukan sebuah kegiatan atau aktivitas. Penurunan kesehatan akan mengakibatkan tubuh merasa sakit dan mudah terkena penyakit sehingga mengganggu kegiatan sehari-hari. Oleh karena itu, diperlukan obat untuk mengurangi rasa sakit dan meningkatkan daya tahan tubuh untuk mencegah terjadinya penyakit. Rasa nyeri atau sakit timbul karena ada rangsangan mekanis ataupun kimiawi sehingga jaringan tubuh melepaskan zat-zat yang disebut mediator peradangan seperti bradikinin, histamin, serotonin, dan prostaglandin. Obat yang berfungsi menghilangkan atau mengurangi rasa sakit adalah obat analgesik. Obat analgesik secara selektif menghilangkan rasa sakit dengan mempengaruhi sistem saraf pusat atau pada mekanisme nyeri tepi tanpa menghilangkan kesadaran (Meen, 2019).

Stamina merupakan daya tahan tubuh untuk melakukan aktivitas secara terus menerus. Stamina tubuh dipengaruhi oleh beberapa faktor di antaranya yaitu makanan, aktivitas yang dilakukan, dan sistem kekebalan tubuh. Makhluk hidup membutuhkan energi agar dapat melakukan aktivitas. Kebutuhan energi akan semakin besar seiring tingginya aktivitas yang dilakukan. Energi untuk meningkatkan stamina diperoleh dari makanan yang dikonsumsi. Selain itu, obat-obatan atau minuman penambah stamina seringkali digunakan untuk meningkatkan stamina tubuh. Terdapat banyak jenis obat-obatan atau minuman untuk meningkatkan stamina yang tersedia di pasaran, namun kandungan kimia dalam obat-obatan atau minuman tersebut dapat membahayakan bagi kesehatan jika dikonsumsi dalam jangka waktu yang panjang.

Penelitian ini bertujuan mempelajari efektivitas infusa kemiri sebagai analgesik. Selain itu, tujuan dari penelitian ini juga untuk mengkaji kemampuan kemiri dalam meningkatkan stamina tubuh. Penelitian ini diharapkan dapat memberikan informasi mengenai biji kemiri dan penggunaannya sebagai analgesik dan stimulator stamina tubuh. Diharapkan penelitian ini juga menjadi alternatif untuk analgesik dan stimulator stamina tubuh yang aman, murah, dan efektif.

\section{BAHAN DAN METODE}

\section{Bahan Penelitian}

\section{Hewan coba}

Hewan coba yang digunakan dalam penelitian ini adalah mencit jantan dengan bobot badan berkisar $20-30$ g. Hewan coba ditempatkan pada kandang berupa boks plastik berukuran sekitar $55 \times 37 \times 17$ $\mathrm{cm}$ dan ditutup menggunakan kawat. Setiap kandang dilengkapi tempat minum dan sekam kayu sebagai alas kandang. Kandang dibersihkan seminggu sebelum penelitian. Mencit dilakukan aklimatisasi agar dapat menyesuaikan dengan kondisi kandang yang baru dan mengurangi stres. Aklimatisasi dilakukan selama 7 hari dengan diberikan air minum ad libitum, pakan, obat cacing, vitamin C, dan antibiotik amoxicillin.

Koleksi dan pembuatan infusa kemiri.

Kemiri dibeli dari pasar Dramaga sebanyak $1 \mathrm{~kg}$. Bagian kemiri yang dibeli merupakan bijinya. Biji kemiri dikeringkan dengan cara dijemur di bawah cahaya matahari. Setelah kering, biji kemiri dihaluskan menggunakan blender. Kemiri yang telah halus, ditimbang sebanyak $50 \mathrm{~g}$ dan ditambahkan akuades sebanyak $100 \mathrm{~mL}$ kemudian direbus pada suhu $90{ }^{\circ} \mathrm{C}$ selama 15 menit. Infusa kemiri didinginkan dan disaring 
menggunakan saringan teh kemudian dimasukkan ke dalam botol plastik. Infusa kemiri disimpan di dalam refrigerator bersuhu $4-5^{\circ} \mathrm{C}$.

\section{Metode Penelitian}

Penelitian ini telah memenuhi kaidah etika penelitian dari Komisi Kesejahteraan Hewan Fakultas Kedokteran Hewan IPB sesuai dengan sertifikat ethical clearance No. 166/KEH/SKE/XII/2019. Selanjutnya, tahapan penelitian diuraikan sebagai berikut.

Pembagian kelompok mencit dan pemberian infusa kemiri

Mencit dibagi menjadi 4 kelompok berdasarkan dosis perlakuan. Setiap kelompok terdapat 5 ekor mencit. Kelompok dosis o (kontrol) tidak diberikan infusa kemiri dan hanya diberikan akuades, sedangkan kelompok lainnya diberikan infusa kemiri dengan dosis masing-masing sebanyak 1, 2, dan 4 $\mathrm{g} / \mathrm{kg}$ BB. Sebelum pencekokan, infusa kemiri dihomogenkan dengan cara dikocok. Mencit di-handle pada bagian tengkuk atau kulit di belakang leher dan ditahan dalam posisi tegak. Infusa kemiri diberikan atau dicekok secara oral menggunakan sonde lambung langsung ke esofagus distal yang akan memasuki lambung. Mencit dicekok berdasarkan dosis perlakuan setiap kelompok, kemudian ditunggu selama 5 menit untuk memberi kesempatan agar bahan uji dapat terdistribusi secara merata di dalam tubuh. Pencekokan infusa dilakukan sebelum uji untuk mengetahui efek analgesik sebanyak tiga kali ulangan pada hari yang berbeda dengan selang waktu satu hari yaitu pada hari ke-1, 3, dan 5 .

\section{Uji analgesik}

Uji untuk mengetahui efek analgesik dilakukan menggunakan metode hot water immersion tail-flick test dengan cara membenamkan sebagian ekor mencit ke dalam penangas air. Metode ini banyak digunakan untuk mengukur derajat nosisepsi yang dialami hewan laboratorium. Respons yang diberikan berupa pengibasan atau penarikan ekor hewan uji secara tiba-tiba (Yusuf, 2001; Zhou et al., 2014). Pengujian untuk mengetahui efek analgesik dilakukan dengan cara mencit di-handle pada bagian tengkuk atau kulit di belakang leher, kemudian sebagian ekor dibenamkan pada penangas air dengan suhu $50{ }^{\circ} \mathrm{C}$. Waktu yang diperlukan dari awal ekor dibenamkan hingga ekor dikibaskan dihitung menggunakan stopwatch. Rata-rata waktu pada masing-masing kelompok dihitung dan dibandingkan dengan kontrol. Pengujian diulang sebanyak tiga kali ulangan pada hari yang berbeda dengan selang waktu satu hari yaitu pada hari ke-1, 3, dan 5 .
Uji stamina

Pengujian stamina dilakukan setelah uji untuk mengetahui efek analgesik. Metode pengujian stamina menggunakan metode ketahanan berenang atau swimming endurance. Metode ini merupakan screening farmakologi yang dilakukan untuk mengetahui efek obat yang bekerja pada koordinasi gerak, baik pengujian terhadap penurunan kontrol saraf pusat maupun peningkatan kontrol saraf pusat (Lukman dan Vivi, 2018). Mencit yang telah diuji analgesik diistirahatkan selama 5 menit, kemudian dimasukkan ke dalam kolam pengujian swimming endurance ukuran $55 \times 35 \times 17 \mathrm{~cm}$. Waktu dari awal mencit berenang hingga mencit tidak bergerak di dalam air dihitung menggunakan stopwatch. Rata-rata durasi pada masing-masing kelompok dihitung dan dibandingkan. Pengujian diulang sebanyak tiga kali ulangan pada hari yang berbeda dengan selang waktu satu hari yaitu pada hari ke-1, 3, dan 5 .

\section{Analisis Data}

Analisis data dilakukan dengan menggunakan Microsoft Excel® dan Minitab $19{ }^{\circledR}$. Perbedaan yang signifikan dari rata-rata setiap kelompok ditunjukkan secara statistik menggunakan uji Analysis of Variance (ANOVA) one way dan uji Tukey.

\section{HASIL}

Berdasarkan hasil penelitian, kelompok dosis yang diberikan infusa kemiri pada ulangan pertama dan kedua tidak berbeda nyata ( $p>0.05$ ) pada setiap dosis. Waktu respons nyeri pada ulangan pertama dengan dosis 1 , 2, dan $4 \mathrm{~g} / \mathrm{kg}$ BB secara berturutturut sebesar $1.40 \pm 0.10,1.26 \pm 0.17$, dan $1.22 \pm 0.05$ detik sedangkan pada ulangan kedua secara berturut-turut sebesar $1.90 \pm 0.25, \quad 2.60 \pm 1.10$, dan $3.87 \pm 1.41$ detik. Kelompok perlakuan pada ulangan ketiga berbeda nyata $(p<0.05)$ setiap dosis kecuali pada dosis $1 \mathrm{~g} / \mathrm{kg}$ BB. Waktu respons nyeri pada ulangan ketiga dengan dosis 1, 2, dan $4 \mathrm{~g} / \mathrm{kg}$ BB secara berturut-turut sebesar $2.50 \pm 0.19,4.54 \pm 0.48$, dan 7.84 \pm 0.48 detik.

Penurunan waktu respons nyeri setiap kelompok dosis pada ulangan pertama terjadi karena kondisi stres akibat mencit belum beradaptasi terhadap pengujian untuk mengetahui efek analgesik. Waktu respons nyeri pada dosis 2 dan $4 \mathrm{~g} / \mathrm{kg}$ BB meningkat pada ulangan kedua dan ketiga dikarenakan mencit mulai beradaptasi sehingga aktivitas farmakologis obat dalam infusa kemiri bekerja lebih efektif. Waktu respons nyeri tertinggi ditunjukkan oleh kelompok mencit dengan pemberian dosis $4 \mathrm{~g} / \mathrm{kg} \mathrm{BB}$. 
Pengaruh pemberian dosis terhadap efek analgesik yang dihasilkan cenderung meningkat meskipun pada dosis $1 \mathrm{~g} / \mathrm{kg}$ BB mengalami penurunan. Hubungan antara dosis pemberian terhadap efek analgesik ini ditunjukkan pada Gambar 1.

Gambar 1 menunjukkan bahwa pemberian infusa kemiri secara umum mengalami peningkatan di setiap pengulangan pada masing-masing dosis. Waktu respons nyeri kelompok dosis 1, 2, dan $4 \mathrm{~g} / \mathrm{kg}$ BB pada ulangan pertama menunjukkan penurunan dibandingkan dengan kontrol. Pengulangan kedua dan ketiga mulai menunjukkan peningkatan waktu respons nyeri pada dosis $2 \mathrm{~g} / \mathrm{kg}$ BB dan dosis $4 \mathrm{~g} / \mathrm{kg}$ $\mathrm{BB}$ sedangkan dosis $1 \mathrm{~g} / \mathrm{kg}$ BB mengalami penurunan dibandingkan dengan kontrol.

Hasil penelitian menunjukkan bahwa pemberian infusa kemiri dapat meningkatkan potensi analgesik. Pemberian infusa kemiri yang efektif untuk mening- katkan potensi analgesik yaitu dosis $4 \mathrm{~g} / \mathrm{kg}$ BB dengan nilai rata-rata sebesar 4.309 \pm 2.926 detik. Nilai rata-rata keseluruhan pada setiap ulangan pemberian infusa kemiri pada dosis $4 \mathrm{~g} / \mathrm{kg}$ BB tersebut lebih besar dibandingkan dengan kontrol dan dosis lainnya. Interaksi antara pemberian dosis infusa kemiri berbanding lurus dengan efek yang dihasilkan pada pengujian. Semakin tinggi dosis pemberian infusa kemiri maka efek analgesik yang dihasilkan akan semakin tinggi.

Durasi berenang dicatat kemudian dihitung nilai rata-rata setiap dosis dan dibandingkan dengan kontrol. dihitung pula nilai rata-rata total seluruh ulangan kelompok dosis dan kelompok kontrol kemudian dibandingkan. Hasil durasi berenang ditunjukkan pada Tabel 1. Berdasarkan hasil penelitian, secara keseluruhan kelompok dosis $1 \mathrm{~g} / \mathrm{kg}$ BB menghasilkan efek stimulasi lebih tinggi dibandingkan dengan efek

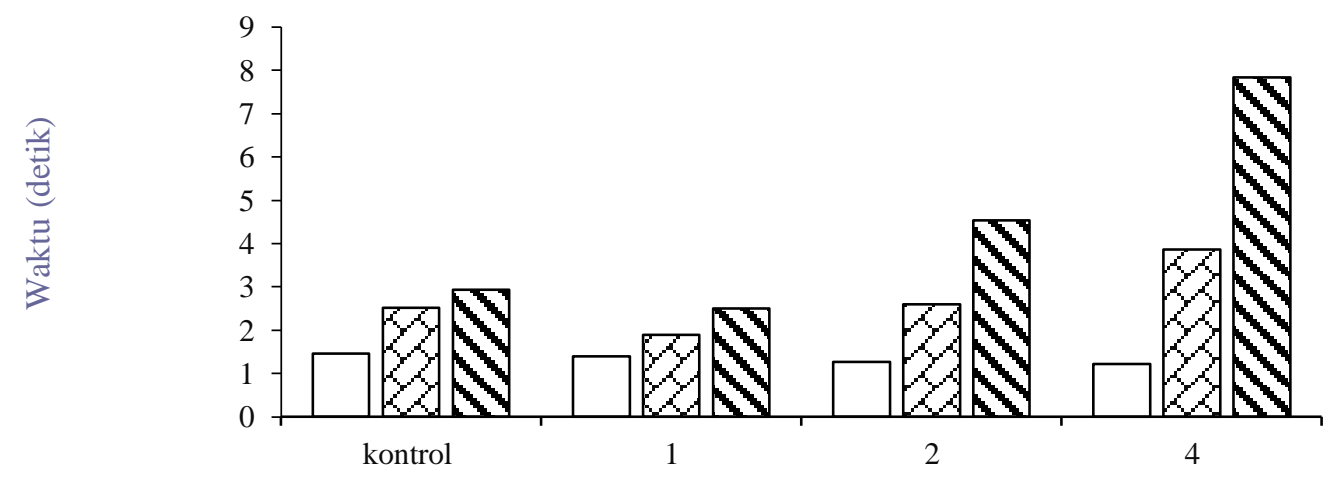

Dosis $\mathrm{g} / \mathrm{kg} \mathrm{BB}$

Gambar 1 Hubungan pengaruh pemberian dosis terhadap waktu respons nyeri ( $\square$ Ulangan 1 ; UUlangan $2 ;$ sUlangan 3 )

Tabel 1 Durasi berenang (detik) pada berbagai dosis infusa kemiri

\begin{tabular}{ccccc}
\hline \multirow{2}{*}{ Ulangan } & \multicolumn{4}{c}{ Dosis $(\mathrm{g} / \mathrm{kg} \mathrm{BB})$} \\
\cline { 2 - 5 } & Kontrol & 1 & 2 & 4 \\
\hline 1 & $35.20 \pm 7.56^{\mathrm{b}}$ & $75.80 \pm 5.22^{\mathrm{a}}$ & $63.00 \pm 5.87^{\mathrm{a}}$ & $48.60 \pm 11.57^{\mathrm{b}}$ \\
2 & $71.40 \pm 12.42^{\mathrm{b}}$ & $105.40 \pm 11.13^{\mathrm{a}}$ & $90.40 \pm 4.51^{\mathrm{a}}$ & $69.60 \pm 2.79^{\mathrm{b}}$ \\
3 & $92.80 \pm 11.21^{\mathrm{bc}}$ & $145.00 \pm 20.65^{\mathrm{a}}$ & $127.2 \pm 26.6^{\mathrm{ab}}$ & $87.20 \pm 13.70^{\mathrm{c}}$ \\
Rata-rata & $66.47 \pm 26.49^{\mathrm{c}}$ & $108.73 \pm 32.03^{\mathrm{a}}$ & $93.53 \pm 30.96^{\mathrm{ab}}$ & $68.47 \pm 19.00^{\mathrm{bc}}$ \\
\hline
\end{tabular}

Keterangan : Huruf (superscript) yang berbeda pada baris yang sama menunjukkan berbeda nyata $(p<0.05)$ 
stimulasi lebih tinggi dibandingkan dengan kelompok kontrol, kelompok dosis 2, dan $4 \mathrm{~g} / \mathrm{kg}$ BB dilihat dari durasi berenang yang lebih lama. Pada ulangan pertama, dosis $1 \mathrm{~g} / \mathrm{kg}$ BB memiliki nilai ratarata $75.80 \pm 5.22$ detik, lebih tinggi dari dosis $2 \mathrm{~g} / \mathrm{kg}$ BB sebesar $63.00 \pm 5.87$ detik dan dosis $4 \mathrm{~g} / \mathrm{kg}$ BB sebesar $48.60 \pm 11.57$ detik. Hal serupa juga terjadi pada ulangan kedua dan ketiga. Nilai rata-rata total ulangan dari yang tertinggi hingga terendah untuk kelompok dosis secara berturut-turut adalah pada dosis 1 , 2, dan $4 \mathrm{~g} / \mathrm{kg}$ BB. Nilai rata-rata total pada kelompok dosis ini masih lebih tinggi daripada nilai rata-rata total kelompok kontrol (Tabel 1). Pengaruh pemberian dosis terhadap durasi berenang meningkat pada dosis $1 \mathrm{~g} / \mathrm{kg}$ BB kemudian menurun seiring peningkatan pemberian dosis. Hubungan antara dosis pemberian terhadap efek stamina ini ditunjukkan pada Gambar 2.

Efek stimulasi mengalami peningkatan secara bertahap dari ulangan pertama hingga ulangan ketiga dengan urutan nilai rata-rata dari tertinggi secara berturut-turut adalah pada dosis 1, 2, dan 4 $\mathrm{g} / \mathrm{kg} \mathrm{BB}$. Durasi ketahanan berenang paling tinggi dibandingkan dengan dosis lain adalah pada dosis $1 \mathrm{~g} / \mathrm{kg}$ BB sehingga keefektifan infusa kemiri sebagai stimulator stamina ditunjukkan pada dosis 1 $\mathrm{g} / \mathrm{kg}$ BB. Gambar 2 menunjukkan semakin tinggi pemberian dosis maka durasi berenang akan semakin kecil sehingga keefektifan infusa kemiri juga semakin menurun. Hal tersebut menunjukan bahwa interaksi antara dosis dan efek yang dihasilkan berbanding terbalik.

\section{PEMBAHASAN}

Penelitian ini dilakukan untuk mempelajari potensi kemiri dalam meningkatkan efek analgesik dan stimulator stamina pada mencit. Hewan percobaan yang digunakan adalah mencit jantan karena kondisi hormonal dan kondisi stres yang lebih stabil dibandingkan dengan mencit betina (Lukman \& Vivi, 2013).

Reaksi yang diamati pada pengujian potensi analgesik adalah waktu yang diperlukan untuk mengibaskan ekor sebagai respons nyeri terhadap panas. Potensi analgesik kemiri diindikasikan oleh peningkatan waktu respons nyeri kelompok mencit yang diberi perlakuan atau dalam penelitian ini disebut dengan kelompok dosis dibandingkan dengan kelompok kontrol. Waktu respons nyeri dicatat dari awal perendaman hingga respons kibas ekor kemudian dihitung nilai rata-rata setiap dosis dan dibandingkan dengan kontrol. Dihitung pula nilai rata-rata total seluruh ulangan kelompok dosis dan kelompok kontrol kemudian dibandingkan. Hasil waktu respons nyeri seperti ditunjukkan pada Tabel 2.

Berdasarkan Tabel 2 waktu respons nyeri dilihat dari dosisnya menunjukkan dosis $1 \mathrm{~g} / \mathrm{kg}$ BB tidak berbeda nyata dibandingkan dengan kontrol. Hal ini diduga karena pemberian infusa pada mencit kelompok dosis $1 \mathrm{~g} / \mathrm{kg}$ BB tidak menghasilkan aktivitas farmakologis dan tidak menghasilkan efek analgesik. Pemberian dosis rendah akan mempengaruhi jumlah absorbsi obat yang terkandung dalam infusa kemiri tersebut. Pengurangan jumlah absorbsi akan mengakibatkan pengobatan menjadi tidak efektif (Cahyono, 2008).

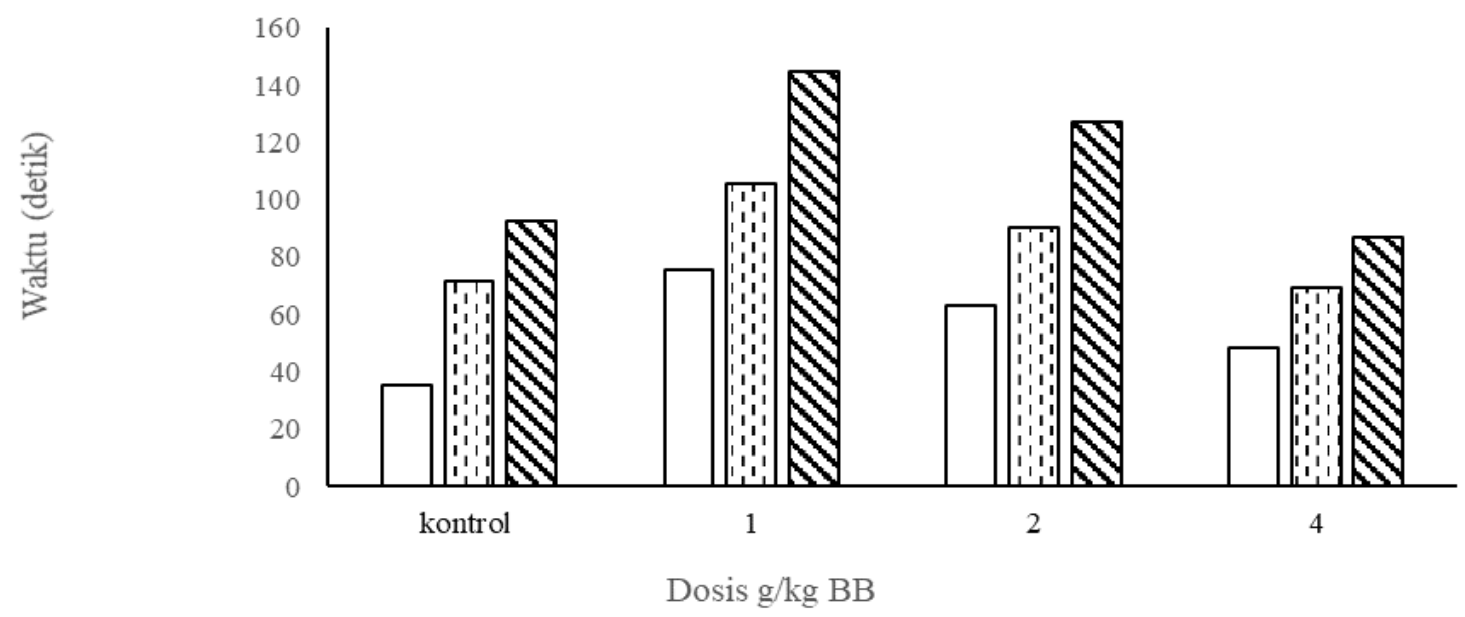

Gambar 2 Hubungan antara pengaruh pemberian dosis terhadap durasi berenang ( $\square$ Ulangan 1 ; $\square$ Ulangan 2 ; $\Delta$ Ulangan 3’) 
Tabel 2 Waktu respons nyeri ekor (detik) pada berbagai dosis infusa kemiri

\begin{tabular}{ccccc}
\hline \multirow{2}{*}{ Ulangan } & \multicolumn{4}{c}{ Dosis $(\mathrm{g} / \mathrm{kg} \mathrm{BB})$} \\
\cline { 2 - 5 } & Kontrol & 1 & 2 & 4 \\
\hline 1 & $1.46 \pm 0.21^{\mathrm{a}}$ & $1.40 \pm 0.10^{\mathrm{a}}$ & $1.26 \pm 0.17^{\mathrm{a}}$ & $1.22 \pm 0.05^{\mathrm{a}}$ \\
2 & $2.52 \pm 0.29^{\mathrm{ab}}$ & $1.90 \pm 0.25^{\mathrm{b}}$ & $2.60 \pm 1.10^{\mathrm{ab}}$ & $3.87 \pm 1.41^{\mathrm{a}}$ \\
3 & $2.94 \pm 0.09^{\mathrm{c}}$ & $2.50 \pm 0.19^{\mathrm{c}}$ & $4.54 \pm 0.48^{\mathrm{b}}$ & $7.84 \pm 0.48^{\mathrm{a}}$ \\
Rata-rata & $2.31 \pm 0.67^{\mathrm{b}}$ & $1.93 \pm 0.50^{\mathrm{b}}$ & $2.80 \pm 1.54^{\mathrm{ab}}$ & $4.31 \pm 2.93^{\mathrm{a}}$ \\
\hline
\end{tabular}

Keterangan : Huruf (superscript) yang berbeda pada baris yang sama menunjukkan berbeda nyata $(p<0.05)$

Berdasarkan Tabel 2 waktu respons nyeri dilihat dari dosisnya menunjukkan dosis $1 \mathrm{~g} / \mathrm{kg}$ BB tidak berbeda nyata dibandingkan dengan kontrol. Hal ini diduga karena pemberian infusa pada mencit kelompok dosis $1 \mathrm{~g} / \mathrm{kg}$ BB tidak menghasilkan aktivitas farmakologis dan tidak menghasilkan efek analgesik. Pemberian dosis rendah akan mempengaruhi jumlah absorbsi obat yang terkandung dalam infusa kemiri tersebut. Pengurangan jumlah absorbsi akan mengakibatkan pengobatan menjadi tidak efektif (Cahyono, 2008).

Kemiri dapat meningkatkan potensi analgesik karena senyawa aktif yang terkandung didalamnya. Menurut Niazi et al. (2010), ekstrak metanol kemiri (Aulerites moluccana) dapat meningkatkan aktivitas analgesik karena memiliki senyawa alkaloid, sterol, dan flavonoid. Kemiri juga dapat menyembuhkan luka kulit, ulser, diare, asma, dan meningkatkan efek analgesik (Singh et al., 2010).

Pengujian stamina dilakukan setelah pengujian efek analgesik menggunakan metode ketahanan berenang (swimming endurance) dengan mengukur durasi waktu daya tahan mencit saat berenang tanpa mengalami kelelahan. Potensi stimulator stamina diindikasikan pada peningkatan durasi waktu dari awal berenang (fase struggling) hingga mencit mulai menunjukkan kelelahan dan tidak bergerak (fase floating). Pemberian infusa kemiri dapat meningkatkan stimulasi stamina dengan dosis tertentu. Dalam penelitian ini, dosis optimum yang dapat meningkatkan stimulasi stamina adalah dosis $1 \mathrm{~g} / \mathrm{kg}$ BB. Pemberian dosis yang berlebih akan menurunkan stamina tubuh. Menurut Yuliarti (2010), obat herbal pada dosis kecil akan bersifat sebagai stimulator sedangkan pada dosis yang besar akan bersifat sebagai depressor.

Menurut Soesanty dan Samsudin (2013), dalam penelitiannya menunjukkan bahwa kemiri mengandung flavonoid, alkaloid, saponin, fenolik, triterpenoid, dan glikosida. Senyawa flavonoid bersifat sebagai anti inflamasi yang menghambat pembentukan radang penyebab nyeri. Mekanisme flavonoid sebagai anti inflamasi adalah dengan menghambat enzim siklooksigenase 1 yang berperan dalam biosentesis prostaglandin sehingga akan menghambat timbulnya rasa nyeri dan meningkatkan efek analgesik (Afrianti et al. 2014).

Senyawa flavonoid memberikan efek terhadap peningkatan analgesik didukung oleh penelitian Xiao et al. (2016), bahwa flavonoid memiliki aktivitas biologis yang berperan sebagai analgesik dengan efek samping yang kecil. Selain memiliki efek analgesik, flavonoid juga dapat meningkatkan stamina. Flavonoid dapat meningkatkan stamina karena menghambat enzim fosfodiesterase yang berfungsi mengubah siklik AMP menjadi AMP yang kemudian akan mengaktifkan enzim fosforilakinase yang akan mengubah glikogen menjadi glukosa 1 fosfat. Glukosa 1 fosfat kemudian diubah menjadi glukosa 6 fosfat oleh enzim glukofosfomutase. Pembentukan glukosa 6 fosfat akan menjadi tambahan sumber energi dalam menjalankan aktivitas (Rahmi et al., 2018). Flavonoid juga memiliki sifat stamina dengan meningkatkan kandungan glikogen hepatik dan mengurangi asam laktat di otot (Li \& Zhang, 2013).

Produk yang dapat meningkatkan stamina mengandung satu atau lebih vitamin, mineral atau bahan dari tumbuhan (Aulawi, 2005). Di dalam kemiri terkandung zat mikro yang terdiri atas mineral seperti kalium, fosfor, magnesium, kalsium, besi, seng, tembaga, dan selenium. Mikronutrien ini terlibat dalam berbagai proses biologis yang relevan dengan olahraga dan kinerja atletik, seperti penyimpanan atau pemanfaatan energi, metabolisme protein, peradangan, transportasi oksigen, irama jantung, metabolisme tulang, dan fungsi kekebalan tubuh (Heffernan et al., 2019). Senyawa lain yang dapat meningkatkan stamina adalah senyawa fruktosa, glukosa, dan maltosa yang terkandung dalam kemiri (Bilang et al., 2018). Glukosa merupakan 
senyawa organik yang mudah dicerna dan berperan sebagai sumber energi untuk proses metabolisme dalam tubuh (Joyce, 2013).

Berdasarkan hasil penelitian, kemiri terbukti dapat meningkatkan efek analgesik dan meningkatkan stimulasi stamina, namun penggunaan infusa kemiri sebagai pengobatan herbal perlu memperhatikan dosis agar efektif dan aman untuk dikonsumsi. Pada masa yang akan datang, kemiri dapat dijadikan sebagai salah satu alternatif sediaan analgesik dan stimulator stamina alami yang memiliki efek samping relatif rendah jika dibandingkan bahan kimia obat sintetik. Infusa kemiri efektif untuk meningkatkan potensi analgesik dan stimulator stamina.

Berdasarkan penelitian ini, dosis efektif untuk uji analgesik sebesar $4 \mathrm{~g} / \mathrm{kg} \mathrm{BB}$, sedangkan untuk uji stamina sebesar $1 \mathrm{~g} / \mathrm{kg}$ BB. Pada uji analgesik, dosis pemberian berbanding lurus dengan efek yang ditimbulkan, sedangkan uji stamina dosis pemberian berbanding terbalik dengan efek yang ditimbulkan.

\section{UCAPAN TERIMA KASIH}

Ucapan terima kasih penulis sampaikan kepada Unit Pengelola Laboratorium Fakultas Kedokteran Hewan, Institut Pertanian Bogor.

"Penulis menyatakan tidak ada konflik kepentingan dengan pihak-pihak yang terkait dalam penelitian ini".

\section{DAFTAR PUSTAKA}

Adawiyah R. 2017. Uji identifikasi farmakognostik tumbuhan kemiri sunan (Aleurites trisperma) di kebun percobaan Universitas Muhammadiyah Palangkaraya. Anterior J 17(1):60 - 68.

Afrianti R, Yenti R, Meustika D. 2014. Uji aktifitas analgetik ekstrak etanol daun pepaya (Carica papaya L.) pada mencit putih jantan yang diinduksi asam asetat 1\%. J Sains Farm Klin 1(1):54-60.

Aulawi T. 2005. Preferensi Konsumsi Beberapa Produk Suplemen Penstimulasi Stamina (Studi Kasus di Kota Bogor). Tesis S2. Sekolah Pascasarjana, Institut Pertanian Bogor. Bogor.

Bilang M, Mamang, Salengke, Putra RP, Reta. 2018. Elimination of toxalbumin in candlenut seed (Aleurites molucccana ( $\mathrm{L}$ ) Willd) using wet heating at high temperature and identification of compounds in the candlenut glycoprotein. IJAS 6(2):89-100.
Cahyono SY. 2008. Evaluasi Komposisi, Indikasi, Dosis, Dan Interaksi Resep Racikan untuk Pasien Pediatri Rumah Sakit Bethesda Yogyakarta Periode Juli 2007. Skripsi S1. Fakultas Farmasi, Universitas Sanata Dharma Yogyakarta. Yogyakarta.

Heffernan SM, Horner K, Vito GD, Conway GE. 2019. The role of mineral and trace element supplementation in exercise and athletic performance: a systematic review. Nutrient 11(3):1-32.

Joyce LFK. 2013. Pedoman Pemeriksaan Laboratorium \& Diagnostik. Ed 6. EGC. Jakarta.

Li C, Zhang L. 2013. In vivo anti-fatigue activity of total flavonoids from sweetpotato (Ipomoea batatas (L.) Lam.) leaf in mice. IJBB 5:326-329.

Lukman FH, Vivi. 2013. Uji anti lelah (anti fatigue) kombinasi nira aren dan air tebu dengan metode ketahanan berenang (natatory exhaustion) pada mencit jantan. Pharmacy 10(2):124-137.

Meen LX. 2019. Study on Analgesic Effect of Ketapang Leaf Ethanol Extract (Terminalia catappa). Skripsi S1. Fakultas Kedokteran Hewan, Institut Pertanian Bogor. Bogor.

Niazi J, Gupta V, Chakarborty P, Kumar P. 2010. Antiinflammatory and antipyretic activity of Aleuritis moluccana leaves. AJPCR 3(1):35-37.

Nurrani L. 2013. Pemanfaatan tradisional tumbuhan alam berkhasiat obat oleh masyarakat di sekitar cagar alam Tangale. Info Balai Penelitian Kehutanan Manado 3(1):1-22.

Rahmi M, Tobat SR, Ningsih S. 2018. Uji efek stimulan sistem saraf pusat ekstrak etanol daun Afrika Selatan (Vernonia amygdalina delile) pada mencit putih betina. SCIENTA J Far Kes 8(2):137-143.

Singh MK, Nagori K, Tripathi DK. 2010. Potential analgesic \& anti-pyretic herbal drugs: a comparative review of markered product. IJP 2:197-209.

Soesanty F, Samsudin. 2013. Peranan ekstrak babadotan dan bawang putih serta minyak kemiri sunan terhadap serangan penggerek buah kakao. Buletin RISTRI 4(2):15.

Xiao X, Wang X, Gui X, Chen L, Huang B. 2016. Natural flavonoids as promising analgesic candidates: a systematic review. Chem Biodivers 13(11):1427-1440.

Yuliarti N. 2010. Sehat, Cantik, Bugar dengan Herbal dan Obat Tradisional. Penerbit Andi. Yogyakarta.

Yusuf H. 2001. Efek Analgesia Infusa Daun Klausena (Clausena anisa Hook.f.) pada Tikus Putih dengan Metode Rat Tail Analgesy Test. Skripsi S1. Fakultas Kedokteran, Universitas Sumatera Utara. Medan.

Zhou Q, Bao Y, Zhang X, Zeng L, Wang L, Wang J, Jiang W. 2014. Optimal interval for hot water immersion tail-flick test in rats. Acta neuropsychiatr 26(4):218-222. 